at the Radar Research and Development Establishment, Malvern, and worked on high-power precision tracking radars. On the amalgamation of the Radar Research and Development Establishment with the Telecommunications Research Establishment to form the Royal Radar Establishment, he joined the Guided Weapon Department and in 1955 he became superintendent, surface-to-air guided weapons guidance systems. In this post he has been responsible for research on new guidance techniques which now form the basis of the future systems for the air defence of the United Kingdom and the field army. $\mathrm{H}_{e}$ has also been responsible for the development of tracking radars and other components of the systems and for the technical co-ordination of the complete systems.

\section{The Central Botanical Laboratory, Allahabad :}

Dr. E. K. Janaki Ammal

Dr. E. K. Janaki Ammal retired from the post of director of the Central Botanical Laboratory, Botanical Survey of India, Allahabad, on October 13, 1959. Dr. Janaki Ammal has been intimately associated with the reorganization of the Botanical Survey of India, first as officer on special duty (1952-53) and as director, Central Botanical Laboratory. Dr. Ammal is widely known for the "Chromosome Atlas of Cultivated Plants" which she compiled with Dr. C. D. Darlington. She is at present officer on special duty, Regional Research Laboratory, Jammu (in Kashmir State).

Dr. G. S. Puri

Dr. G. S. PurI has been appointed director of the Central Botanical Laboratory, Allahabad, in succession to Dr. E. K. Janaki Ammal. Dr. Puri has had a varied experience during his past twenty-five years of botanical career. $\mathrm{He}$ has done work of international recognition in palæobotany, phytogeography and ecology, and had the privilege of working with Prof. Birbal Sahni at Lucknow and Prof. W. H. Pearsall at London. He was forest ecologist at the Forest Research Institute, Dehra Dun, for about ten years and during the past three years as regional botanist of the Western Circle of the Botanical Survey of India he completed a reconnaissance survey of the vegetation of western India. Dr. Puri has published about 200 botanical papers, including two major books, the "Indian Manual of Plant Ecology" and "Forest Ecology".

\section{The Australian Academy of Science}

THe following new Fellows of the Australian Academy of Science have recently been elected: Prof. A. E. Alexander, professor of applied chemistry, University of New South Wales; Prof. G. M. Badger, professor of organic chemistry, University of Adelaide; Dr. S. Fazekas de St. Groth, reader in virology, John Curtin School of Medical Research, Australian National University; Prof. K. J. LeCouteur, professor of theoretical physics, Research School of Physical Sciences, Australian National University; Dr. J. M. Rendel, ehief of the Division of Animal Genetics, Commonwealth Scientific and Industrial Research Organization; Dr. F. W. G. White, chairman of the Commonwealth Scientific and Industrial Research Organization.

The Thomas Ranken Lyle Medal for 1959 was presented to Prof. E. S. Barnes, professor of mathematies in the University of Adelaide, who delivered an address on number theory, his special field of work in mathematics.

\section{Awards of the Meldola Medal for 1959}

THe Meldola Medal, which is the gift of the Society of Maccabaeans, is normally awarded annually. On four occasions in the past, two candidates have been adjudged to be of equal merit in diverse fields of work and two awards were made. This year it has again been decided to make two awards of the Meldola Medal. The recipients will be Dr. J. I. G. Cadogan, Department of Chemistry, King's College, London, for his work in the field of organic chemistry, with special reference to reactions of free radicals in solution and to reactions of organophosphorus compounds; and Dr. T. C. Waddington, Department of Chemistry, University of Cambridge, for his work in the fields of physical and inorganic chemistry, with special reference to thermochemistry and reactivity of azides; photoconductivity of anthracene; lattice energies and infra-red spectra of inorganic salts; and liquid hydrogen chloride as an ionizing solvent.

\section{The Food Research Advisory Committee}

Mr. J. B. GodBer, Joint Parliamentary Secretary to the Ministry of Agriculture, Fisheries and Food, recently stated that the Minister and the Secretary of State for Scotland had set up a committee, under the chairmanship of the Permanent Secretary of the Ministry of Agriculture, Fisheries and Food, to assist them in advising the Agricultural Research Council on priorities in Government food research. This was in a written answer to a question in the House of Commons as to the arrangements for ensuring that the technical problems of the food industry are brought to the notice of the Agricultural Research Council now that the Council is responsible for the three Government research stations concerned with the handling and processing of foodstuffs. The Committee would be known as the Food Research Advisory Committee and its terms of reference would be : "To advise on those food problems (except for fish, which is dealt with separately) requiring investigation or research which should be undertaken with the aid of publie funds and to make recommendations as to the priorities to be accorded to such problems". In addition to the chairman, Mr. E. Capstick, Dr. D. P. Cuthbertson, Sir Charles Dodds, Mr. J. D. Hutchison, Mr. D. Lowe, Mr. A. Sainsbury, Sir William Slater, Dr. J. A. B. Smith, Mr. T. A. H. Sycamore, Mr. J. P. Van den Bergh, Sir George Wilson and Mr. N. Wood had accepted invitations to be members of the Committee.

\section{Ford Research Fellowships in Animal Reproduction}

THE Ford Foundation has made a grant of 550,000 dollars $(£ 196,000)$ to the Zoological Society of London to endow a series of research fellowships in animal reproduction. Our present knowledge of reproductive processes is derived mainly from observations on a limited number of species, such as rats, mice, rabbits, guinea pigs, monkeys, and farm animals; but it is sufficient to show that there is great diversity in reproductive mechanisms. We know that some species are continuous breeders and that others are seasonal; that some animals ovulate spontaneously and that others do so only as a result of various forms of external stimulation. These differences have always served as pointers to research, which has in turn 